\title{
DA MORTE DA ARTE EM HEGEL A SUA EXISTÊNCIA AUTÔNOMA
}

Custódio Luís S. de Almeida*

SÍNTESE - Este artigo é um diálogo com Hegel e Gadamer, partindo da pergunta: "O que é arte?". Hegel é um divisor de águas; pode-se dizer que a arte antes de Hegel é uma coisa e depois de Hegel outra. Com Hegel diremos que a arte "morreu" ou foi supra-assumida pelo espírito absoluto; se isso näo significa morte, é, pelo menos, perda de identidade - de autonomia. Com Gadamer diremos que a arte é arte, sem estar dizendo uma tautologia; pois essa seria a melhor forma de dizer que arte näo tem conceito e nem depende de conceito para ser arte; a arte é enquanto tal, sem pendências e sem dependências.
ABSTRACT - My aim throughout this article is creating a dialogue, including Hegel and Gadamer, about of the question: "what is art?". In this context, Hegel is a very important philosophical reference: we can say that art's conception was fully transformed after Hegel's system, he established the art's death because the "absolute sprit" overcame it; hence, the art missed the identity and autonomy. Gadamer has a different conception about art. He understands that "art is art", simply, and this expression is not a tautology, but indicate that art is every independent of concept, that way, art is as such.

\section{1- 0 que é arte?}

Quero partir da questão “O que é arte?". Não tenho a pretensão de responder a ela, mas isso não significa inexistência de respostas; podemos encontrar muitas respostas - mas, a resposta, talvez não - e são as diferentes respostas que nos fazem sempre retornar à mesma pergunta. Neste trabalho vamos nos confrontar com duas respostas possiveis. A primeira encontraremos no diálogo com Hegel e a segunda, com Gadamer.

Com Hegel sou convidado a sair da contingência para chegar à necessidade; sou convidado a deixar a dúvida diante da escolha das infinitas portas de entrada - o mundo das aparências, do senso comum - para trilhar o caminho que me levará ao porto seguro, à essência - o mundo do conceito. Aqui a arte é o belo engendrado pelo espírito e só no espírito a verdade é encontrável, "só o espíito é verdade".

* Professor do Departamento de Ciências Sociais e Filosofia da Universidade Federal do Ceará e doutorando em Filosofia na PUCRS. 
Em Hegel a arte se torna assunto do passado, morre enquanto arte, perde a sua aura divina, o seu poder representativo do sagrado, perde o seu tempo, a sua idade de ouro, a sua beleza. Em Hegel a arte é parte, é um capítulo no conjunto do sistema filosófico. $\mathrm{E}$ a arte enquanto parte é ainda falsidade, porque a verdade enquanto tal é o todo. ${ }^{1}$ A arte é manifestação do espirito ${ }^{2}$ e somente no espírito pode se apreender o que é espírito. Em Hegel a arte perde sua identidade e submete-se à filosofia.

Mas Hegel "concede" espaço para a arte na Filosofia. O que isso significa? Significa que a arte tem lugar na totalidade do sistema e, por isso, enquanto tal a arte é unilateralidade - existência isolada e abstrata - e somente na totalidade do sistema ela se determina enquanto concreticidade. No sistema a arte morre enquanto pura abstração, isolamento, pontualidade, falsidade, e passa a viver como parte organizada, no mundo superior do espírito absoluto, como verdade.

\begin{abstract}
"Temos na arte um particular modo de manifestação do espirito; dizemos que a arte é uma das formas de manifestação porque o espirito, para se realizar, pode revestir múltiplas formas. O modo particular da manifestação do espírito constitui, essencialmente, um resultado. [...] Assim, é que nunca a filosofia, ao começar qualquer assunto, procede como se esse fosse um começo direto, antes o apresenta como uma derivação, como algo de já demonstrado; a filosofia exige a provação de que o ponto de vista escolhido se impõe como necessário. É a própria filosofia que exige para o começo, para o conceito da arte, um antecedente, a fim de que esse conceito seja um resultado demonstrado, um ponto de chegada necessánio"
\end{abstract}

No diálogo com Gadamer posso ser lançado num estádio, diante de um jogo e, na platéia, tomo parte do jogo e sou agente de possibilidades. Ou, se não estou num campo de jogo, posso estar participando de uma festa, onde se celebra a vida, o tempo e a eternidade; uma festa em que o tempo presente é o precioso presente aqui e agora, real e simbólico. No mundo gadameriano a arte me transporta para um universo infinito, de obras e de artistas. Porém, não paro na obra nem no artista, estou para além de ..., sou traspassado de infinitude e remetido ao encontro, faço parte de um jogo - fico prenhe de possibilidades - sou símbolo, reconhecimento, mas, ao mesmo tempo, não represento nada; sou apenas o aqui $\mathrm{e}$ o agora na celebração do sagrado, do tudo e do nada; não sou meio, mas fim em mim mesmo. Na experiência da arte "compreendo" que em arte o velho não existe, o tempo não é cronológico, a interpretação é secundária. A arte não é a obra de arte exterior, diante da qual me extasio; a arte é a minha interação com o mais, sempre presente na obra da qual tomo parte, por isso mesmo é arte.

Gadamer, falando da experiência da arte, apresenta a tensão entre a finitude e a infinitude; entre o tempo cronológico e o tempo sagrado; entre a unidade e a multiplicidade. Nessa tensão peculiar, a arte é livre de enquadramentos, é possibilidade; o velado se desvela e o explícito se oculta; a arte cresce nesse jogo eterno e efêmero:

\footnotetext{
Cf. Hegel, Fenomenologia do espírito (introdução).

Para Hegel espírito é razão.

Cf. G. W. F. Hegel - Estética, p. 5.
} 
“[...] Na experiência da arte, trata-se do fato de que aprendemos a demorar-nos de um modo específico na obra de arte. Um. demorar-se que se caracteriza por não se tornar aborrecido. Quanto mais nos submergimos nela, demorando-nos, tanto mais eloqüente, rica e múltipla se nos manifestará. A essência da experiência temporal da arte consiste no aprender a demorar-se. E, talvez, seja esta a correspondência adequada a nossa finitude para o que se chama eternidade".

Neste artigo não pretendo desenvolver uma análise minuciosa do tratamento dispensado por Hegel e Gadamer à arte, isso exigiria muito mais. Mas quero caminhar um pouco com eles a partir da pergunta "O que é arte?". Hegel, nesse ponto, é um divisor de águas. Podemos falar, distintamente, da arte antes e depois de Hegel. Com Hegel diremos que a arte "morreu" ou foi supra-assumida pelo espirito absoluto; se isso não significa morte, é, pelo menos, perda de identidade de autonomia. Com Gadamer diremos que a arte é arte, sem que estejamos dizendo uma tautologia; pois essa seria a melhor forma de dizer que arte não tem conceito, ou melhor, que a arte não depende de conceito, nem de sistema e, dessa forma, a arte é enquanto tal, sem pendências e sem dependências.

\section{2 - Arte como Conceito em Hegel}

Para iniciarmos o diálogo com Hegel é necessário situar sua concepção de filosofia, pelo menos para não nos perdermos em considerações soltas. Hegel pensa a filosofia enquanto sistema; para ele, somente pelo sistema é que a filosofia nos dá o conhecimento do universo como totalidade orgânica. $O$ entendimento sistemático da filosofia significa que o campo do saber filosófico é a totalidade; 0 sistema é o todo e somente enquanto todo é possível encontrar a verdade. Quando focamos um ponto do sistema, uma parte, não temos ainda a verdade, temos a "falsidade" da parte, temos a "falsidade" de tudo que ainda não é todo, isto é, parcialidade, unilateralidade, falsidade. Mas, em tudo que é parte há a possibilidade de começo rumo ao todo. Para Hegel, porque a filosofia é o estudo sistemático da totalidade, o saber filosófico começa em qualquer parte: "[...] Mas sendo a filosofia uma totalidade, como tal tem o seu começo em tudo". A parte é como uma porta que conduz ao todo e somente no todo ela encontra seu lugar, sua verdade. Portanto, uma consideração da arte, ou, da filosofia da arte de forma isolada do conjunto, só pode nos dar uma idéia abstrata. E, para sermos coerentes com Hegel, é preciso dizer que não vamos tratar aqui da totalidade do sistema, mas apontar para uma concepção geral de arte, embora uma concepção geral não seja ainda o conceito de arte.

Hegel começa assumindo o significado da palavra estética cunhado no século XVIII por Baumgarten. A partir de então estética passou ser a teoria do belo. Isto esclarece qual o interesse de Hegel pela arte e, principalmente, porque assumindo a filosofia da arte como teoria do belo ele estabelece uma relação necessária entre a Arte e o Belo, tornando este o critério que determina o que é arte.

4 Cf. H. G. Gadamer - La actualidad de lo bello, p. 110-111.

A tradução do espanhol para o português é de minha responsabilidade.

Cf. Hegel, op. cit., p. 05. 
Como sabemos, Hegel assume a posição de que a filosofia trata do que é necessário e não do que é acidental. Portanto, se há uma filosofia da arte ou uma teoria do belo é porque o belo é em si mesmo, não é um acidente efêmero, mas possui existências necessárias. E a Idéia do belo é a chave para a porta que conduz à arte. Se entendemos isso podemos seguir em frente e analisar qual a posição de Hegel sobre a multiplicidade dos objetos particulares denominados obras de arte. Entenderemos, também, porque o ponto de chegada de Hegel, nessas considerações, foi a conclusão: "a arte é para nós coisa do passado" e, principalmente, porque a arte ficou prisioneira do conceito.

A afirmação de Hegel que se segue ratifica o que acabou de ser dito:

"Nós começamos pelo belo como tal. E esta idéia que é una, ir-se-á diferenciando, particularizando, a partir de si própria irá originando a variedade, a multiplicidade, as diferenças, as múltiplas e diversas formas e figuras da arte que, então, se vêm a apresentar como produções necessárias"?

Devemos considerar que o método da filosofia para Hegel tem seu ponto de partida na Unidade Absoluta. O que isso significa? Significa que qualquer conceito é um pressuposto derivado da totalidade do sistema. Lembremos que a verdade enquanto tal é o todo, portanto "o conceito do belo e da arte é um pressuposto advindo do sistema da filosofia". "Esse esclarecimento responde a uma objeção clássica à consideração filosófica da arte, ou seja, a de que o pensamento não poderia jamais alcançar a infinidade do domínio do belo. A objeção seria dura se o conceito de arte fosse construido a partir das particularidades do que se costuma denominar obra de arte, pois a indução não sustenta o conceito - não estamos autorizados a tirar conclusões universais a partir da análise ou observação de fenômenos particulares. Hegel esclarece o seu método de forma afirmativa:

“[...] O que tem de servir de base não é o particular, não são as particularidades, não são os objetos, fenômenos, etc., particulares: é a idéia. Pela idéia, pelo universal se deve começar em tudo e, por conseguinte, também em nosso domínio".?

E se aplicamos o método ao domínio da arte, o ponto de partida é a idéia universal do belo. $O$ belo é o critério definidor da arte e da multiplicidade dos objetos definidos como artísticos e não o contrário. Nesse sentido, Hegel continua:

"Iremos, pois, começar pela idéia do belo. As referidas e pretensas teorias, ao contrário, partem das particularidades para chegarem ao conceito, ao universal. A nós, aparece-nos em primeiro lugar a idéia em si e para si, não a idéia derivada, deduzida de objetos particulares". ${ }^{10}$

$\mathrm{Na}$ introdução à Estética, Hegel parte da distinção entre o belo artístico e o belo natural. Nessa distinção inicial já podemos captar evidências da conclusão de suas considerações. E, também, podemos entender o que ele quer dizer quando

\footnotetext{
Cf. Hegel, op. cit., p. 13.

Cf. Hegel, op. cit., p. 08.

Cf. Hegel, op. cit., p. 05.

Cf. Hegel, op. cit., p. 07.

Cf. Hegel, op. cit., p. 07.
} 
afirma: "É preciso conceber a filosofia como um círculo regressando a si mesmo"." Isso significa que o final é o espírito, o espírito absoluto, e tudo já está contido nele, pois ele é a totalidade; o espírito é a verdade. Hegel não se pergunta pela verdade, pois a verdade não é possibilidade, por isso, não cabe perguntas, a verdade já está dada. ${ }^{12}$ Não há lugar para perguntas porque as respostas estão prontas na relacionalidade do sistema.

Afirmar que 'Hegel não se pergunta pela verdade' é uma fronteira que nos ajuda a compreender a vida da arte antes de Hegel e a morte da arte depois de Hegel. ${ }^{3}$ Por quê? Ora, não se perguntar pela verdade é assumir que a verdade já é verdade antes de qualquer pergunta; implica eliminar a possibilidade, encerrar a realidade e apresentá-la como inexorável; não se perguntar pela verdade é dizer que o melhor é um caminho que já existe e que é suficiente descobri-lo e trilhá-lo. Não se perguntar pela verdade, por fim, é matar a contingência" e sem contingência a arte também é morta.

Podemos agora caminhar com Hegel no sentido de dar uma visão geral da arte; e isso só é possível se o espaço que a arte ocupa no sistema for bem localizado e definido. Hegel apresenta critérios para determinar o espaço da arte. Ele começa por estabelecer o belo como o primeiro critério. Em seguida, ele atribui a beleza ao espírito e distingue a arte enquanto produção espiritual, separando-a das demais produções do espírito. Tendo estabelecido os critérios gerais para identificação da arte, Hegel vai defender a possibilidade de uma filosofia da arte ou de uma teoria do belo e, nesse sentido, ele transporta a arte do mundo sensível para a esfera do inteligivel, o mundo espiritual. Para ser uma ciência filosófica a condição necessária é a realidade do objeto estudado. Portanto, quando Hegel defende o belo (o belo artístico) como objeto de ciência filosófica ele está defendendo sua existência enquanto tal, independente de representações ou quaisquer determinações acidentais.

No início da Estética lemos a expressão: "Esta obra é dedicada à estética, quer dizer: à filosofia, à ciência do belo, e, mais precisamente, do belo artístico, pois dela se exclui o belo natural ${ }^{15}$." Por que a distinção entre o belo natural e 0

$"$ Cf. Hegel, op. cit., p. 5.

12 Cf. Ernst Tugendhat - Autoconciência y autodeterminación. Liçỏes 13 e 14.

13 É importante notar que as expressões "vida da arte antes de Hegel" e "morte da arte depois de Hegel" só têm sentido no sistema de Hegel. Se a verdade é a totalidade e tudo que é parte é verdade parcial ou falsidade, então, o que era arte antes de Hegel o era porque a visão era parcial e abstrata, porque não se pensava a arte no todo, da mesma forma é que depois de Hegel, a arte foi supra-assumida pelo conceito, ganhando concretude na totalidade, perdendo sua unilateralidade e, portanto, sua independência definitiva enquanto arte. Falo definitiva porque não se pode negar que a dependência da arte à religiāo já era anterior a Hegel, no entanto, a existência da religião era garantia da existência da arte. Como em Hegel arte e religiảo, na totalidade do sistema, perdem sua autonomia, então, definitivamente deixam de existir de forma independente.

14 Estou elaborando o entendimento de Hegel sobre arte, para em seguida apresentar brevemente a concepção de Gaciuner, tendo como referência os conceitos de contingência e necessidade. Nesse ponto estou usando a discussão feita por Emst Tugendhat no livro Autoconsciência e Autodeterminação, quando situa sua critica principal a Hegel na impossibilidade da pergunta pela verdade. Para Tugendhat, perguntar pela verdade é perguntar pelo real, pelo possivel e pelo melhor. E essa pergunta é indispensável para garantir a liberdade, a autodeterminação. 
belo artístico? Por que somente o belo artístico é o objeto escolhido pela filosofia? A resposta se deve ao suposto que somente o belo artístico é produto do espírito, portanto, é superior ao belo natural. "Tudo quanto provém do espírito é superior ao que existe na natureza. A pior das idéias que perpasse pelo espírito de um homem, é melhor e mais elevada que uma grandiosa produção da natureza - justamente porque essa idéia participa do espírito, porque o espiritual é superior ao natural". ${ }^{15}$ Essa distinção é bastante fecunda. Sendo o belo artístico produto do espirito, isso implica que somente no espirito o belo se realiza, pois o belo artístico só é belo enquanto participante do espírito e, nesse sentido, depende do espíito e não é fora dele.

A existência no espírito torna um objeto superior a qualquer objeto do mundo material e se existe no espírito não depende do mundo material. Se entendemos o que pensa Hegel com essa distinção, então, entendemos porque logo no início da Estética ele distingue a produção artística como diferente do que é natural e, com isso, mostra que só é possivel atribuir beleza a partir do espírito, da razão. Portanto, se dizemos que a lua, a chuva ou a montanha são belas, não é porque existe beleza na natureza, no mundo material, mas sim porque o espírito fecunda a natureza e a envolve com o que é espiritual, e a natureza, assim fecundada e envolvida, é revestida de beleza, tornando possivel a expressão paradoxal do poeta: quão singular és tu lua, que irradias no infinito a beleza e provocas suspiros aos que te contemplam.

Para Hegel, só é belo o que possui expressão artística; e toda e qualquer expressão artística é necessariamente produção espiritual, por isso, só é arte o que é belo, porque só é belo o que nasce do espírito. Ele afirma: "Podemos, pois, precisar, o objeto do nosso estudo dizendo-o formado pelo domínio do belo e, com maior rigor, pelo domínio da arte". "Por isso é que se existe beleza na natureza é apenas enquanto reflexo do espírito, pois só podemos atribuir beleza ao que é natural enquanto este tem relação com o espirito. Em si mesma a natureza não é bela; a beleza provém do espírito e só pelo espirito o belo se determina.

Já podemos constatar que a arte em Hegel tem seu campo delimitado pela produção espiritual, essa é sua condição necessária. Somente do espirito emana a beleza - a beleza é filha da razão. Nesse sentido, somente a produção humana pode ser chamada de produção artística. Chegamos a uma distinção importantíssima, sabemos já porque Hegel distingue a beleza artística da beleza natural, mas isso ainda não é suficiente para definir o campo estrito da arte, pois não basta ser produção humana (espiritual) para ser arte. É importante partirmos para uma segunda delimitação, determinada pela questão: o que transforma uma produção humana em arte?

Hegel responde a esta questão começando por constatar a existência de obras de arte. Tomar a existência de obra de arte como ponto de partida para se chegar à ciência do belo é um recurso metodológico. Isso não significa que Hegel chega ao belo usando um método indutivo, ao contrário, a indução aqui só é possível porque o belo já é anterior à obra de arte e, por isso, é a sua condição de

16 Cf. Hegel, op. cit., p. 2.

17 Cf. Hegel, op. cit., p. 3. 
possibilidade. Começar pela existência da obra de arte é uma forma de distinguir produção artística de produção não artística, é um modo de justificação direta da possibilidade de uma ciência do belo, é, portanto, um mero recurso e não uma necessidade".

Aqui já devemos distinguir a arte enquanto tal da obra de arte. Por que essa distinção? Isso importa na medida em que a obra de arte enquanto objeto sensível não é determinante da arte. $O$ belo artístico enquanto tal não está exteriorizado na obra de arte, pregado nela, ele a transcende. Hegel está voltado para a ciência filosófica, ele não é um crítico de obras de arte. Para ele, a arte importa enquanto manifestação do espírito, enquanto expressão da beleza espiritual. Uma produção humana é arte quando é envolvida pelo belo, essa é uma resposta universal à pergunta colocada. Mas é uma resposta suficiente? Como eu sei que uma obra de arte é obra de arte e não uma outra produção qualquer.

O primeiro nível de resposta possivel é que reconhecemos uma obra de arte se nela há beleza artística. Portanto, o critério é o belo. Hegel assume plenamente as palavras de Platão: "Deve considerar-se, não os objetos particulares qualificados de belos, mas o Belo". ${ }^{9} \mathrm{E}$ aqui temos que mudar então a pergunta. Fica respondida a questão de como Hegel identifica uma obra de arte, mas não fica respondida a questão de como é possível determinar um critério que distinga o que é belo do que não é belo. A arte é bela, mas o que é a beleza? Não recairemos aqui no mesmo problema das infinitas variações do que se chamou belo na história da arte?

Se queremos uma resposta particular do tipo: 'esta obra é uma obra de arte e esta outra não o é', com certeza Hegel não propõe critérios particulares que conduzam a esse tipo de resposta. $\mathrm{O}$ critério hegeliano não é particular, mas universal: a arte é a Bela Arte. Portanto, criticar uma obra de arte é, no minimo, uma decisão muito complexa, porém, é uma decisão empirica. A verdade é a totalidade, por isso, se olhamos uma obra e se dela pretendemos dizer se é arte ou não, com certeza não o faremos com Hegel.

Se fossem colocadas diante de Hegel algumas obras e se lhe solicitasse separá-las entre arte e não arte, qual seria sua atitude? Sua resposta seria positiva ou ele agiria como Sócrates e reporia a pergunta ao interlocutor sem ousar a ela responder? Penso que a resposta a essa pergunta revela 0 alcance da posição filosófica hegeliana e o distingue de um crítico de arte.

Na primeira tentativa de responder filosoficamente à questão colocada, é preciso recorrer ao sistema. Por essa via o critério referencial seria a Beleza enquanto tal e, portanto, enquanto produto espiritual. Por esse caminho Hegel talvez olhasse as produções artísticas diante dele e não as conseguisse diferenciar essencialmente de qualquer outro artefato produzido pelo homem e, nesse sentido, qual-

18 Quando se diz que Hegel fez um grande trabalho filosófico sobre Estética sem ser conhecedor de obras de arte, não se tira com isso, de maneira alguma, o mérito de seu trabalho, pelo contrário, percebe-se que sua justificação de que a filosofia trabalha com o que é necessánio e essencial e não com o sensivel e efêmero, vale para ele mesmo. E é nesse sentido que é possivel afirmar que o recurso à obra de arte é um mero recurso metodológico para captar a unidade na multiplicidade de formas de manifestação do belo.

19 Cf. Hegel, op. cit., 07. 
quer tentativa de resposta e qualquer posição assumida sobre uma obra seria para ele um problema empírico e não um problema filosófico. Ao filósofo caberia apresentar a estrutura do absoluto e apontar seu horizonte, pensar os princípios universalíssimos de todas as coisas, neste caso um posicionamento particular e pontual sobre uma obra (de arte) caberia a um crítico de arte, a um especialista no assunto. $\mathrm{O}$ filósofo pensa $\mathrm{O}$ absoluto do qual fazem parte a arte e a religião, no entanto, ser filósofo para Hegel não é ser um artista ou um religioso, mas é ser ao mesmo tempo artista e religioso, pois o espírito que se engendra a si mesmo não carece de mais nada, e do alto de sua autonomia e contemplando o Belo em si mesmo, simplesmente não reconhece beleza em nada que dele se diferencie. 0 filósofo não carece de arte e de religião porque ao tratar do absoluto ele é artista e religioso no sentido mais elevado: é filósofo. Por esse caminho encontramos a resposta final a que chegou Hegel, de que a arte é coisa do passado, perdeu sua especificidade e foi supra-assumida pela razão no nivel mais alto; com certeza essa seria uma resposta coerente com o seu sistema.

Uma segunda resposta à questão colocada só é possivel se sairmos do sistema. Quando desprezamos o critério colocado por Hegel e assumimos como critério de arte o não-critério, a possibilidade da diferença e do radicalmente novo que pode existir na relação entre a obra e o observador, então saímos da conceitualização e entramos na contingência, no indeterminado e, portanto, na impossibilidade de definir arte. Fica claro que aqui já estamos fora do sistema hegeliano. Enquanto na primeira resposta consideramos uma filosofia da arte e, portanto, uma arte determinada pelo conceito, nesta segunda resposta tratamos de arte de forma indeterminada, da arte mesma como sujeito.

No ponto a que chegamos é coerente dizer que Hegel radicalizou o encontro entre Arte e Filosofia. Sendo a Filosofia o estudo da totalidade, enquanto é busca da Verdade, o ponto qualitativamente superior da sintese entre Arte e Filosofia é o Conceito. No Conceito a Arte perde sua pretensa "autonomia" e "morre". A morte da Arte não é, portanto, o seu desaparecimento, mas sim o seu deslocamento para - Todo, é a sua determinação no Absoluto. Fora do Todo a arte é apenas "falsidade". E, paradoxalmente, para ser percebida no Todo é necessário chegar ao conceito, mas no conceito o espírito prescinde de abstrações unilaterais (falsas) e contempla a Beleza verdadeira.

O melhor que podemos fazer quanto à questão que colocamos acima é dizer que a arte que morreu para Hegel não é a Arte enquanto criação genial ou interação simbólica ou sintese cultural ou nave de prazer e êxtase, mas sim a Arte Bela, a arte sujeitada no conceito - pela necessidade. E livre da conceitualização a arte é viva, mas é fugidia e efêmera, é um misto de real e inefável, ou melhor, é presença inefável (sem limite), é contingência.

Sigamos agora algumas das afirmações de Hegel que podem nos esclarecer um pouco mais a questão colocada. $\mathrm{O}$ argumento a ser desenvolvido é que a arte não tem um fim último em si mesma e que a morte da arte em Hegel não significa morte da arte enquanto fenômeno antropológico; assim como não pode significar o fim da capacidade de criar e de se espantar diante da criação. A morte da arte em Hegel não matou o animal simbólico, nem reduziu o homem ao sistema, mas, ao 
contrário, é fruto de sua mais alta capacidade especulativa e da engenhosidade capaz de conectar momentos diferentes em tempos distintos, dando sentido à multiplicidade das partes, na unidade universal da teia parida de uma mesma matriz filosófica.

E por que a arte, no sistema hegeliano, não é autônoma? Hegel responde: “[...] na arte, como no pensamento, é a verdade que procuramos. Em sua mesma aparência a arte deixa entrever algo que ultrapassa a aparência: o pensamento". A resposta está dada. Tudo é mediação para a Verdade, só na verdade a Beleza é encontrada. Quando o pensamento ainda era tacanho, incapaz de transpor os limites da natureza e dos sentidos, então a obra de arte era a porta indispensável que levava à verdade buscada, ao belo. Mas o pensamento foi criando asas na história e, na maturidade, lançou-se a voar alto, desvencilhou-se dos muros dos labirintos e do alto do vôo vislumbrou a arquitetura que o aprisionava, viu as veredas de cima, de onde vinham e para onde iam: a Verdade foi encontrada na visão inteira do vôo do filósofo, a Beleza foi contemplada do altoon e, por isso, retornar ao labirinto anterior se tornou impossivel.

Antes do vôo a arte era prisioneira, mas para quem não conhece a liberdade a prisão não existe. Assim como na caverna de Platão a sombra era tida como realidade, assim também, na arte, a aparência era tomada como essência, o falso como o verdadeiro. A verdade da unidade diferenciada não era atestada, apenas presumida pela representação; nisto residia a grandeza da arte e do artista, pois, através da obra de arte um mundo ideal se abria no que a obra de arte representava: o mito, o sagrado, o perfeito. Como no sono se abre o mundo dos sonhos assim também " $[. .$.$] em todas as suas representações, a arte põe-nos em presença de um$ princípio superior. Naquilo a que chamamos natura, mundo exterior, muito dificilmente o espírito se encontra, se reconhece" ${ }^{n}$ A arte era a nave que proporcionava a conquista de mundos transcendentes.

Se a verdade é o fim último da religião, da arte e da filosofia, então suas existências estão condicionadas para encontrá-la. Se hoje a arte é coisa do passado é porque se pode prescindir dela para chegar ao destino final. Hegel foi assertivo ao afirmar o espaço comum da arte, religião e filosofia: elas se realizam na sintese final: a verdade absoluta feita conceito.

"O seu mais alto destino, tem-no a arte em comum com a religiảo e com a filosofia. Como estas, também ela é um modo de expressão do divino, das necessidades e exigências mais elevadas do espírito. [...] Mas a arte difere da religião e da filosofia pelo poder de dar, das idéias elevadas, uma representação sensivel que no-las torna acessivel". ${ }^{3}$ "É a arte que nos abre os horizontes das manifestaçōes dessas potências universais, que no-las torna aparentes e sensiveis".

A apreensão sensivel do divino proporcionada pela arte lhe conferia destaque. Se o sensivelmente apreendido na obra de arte tomava acessivel as potências

¿t. Hegel, op. cit., p. 12.

" No inicio do diálogo "Sofista" Platão compara o filósofo a um ser divino, capaz de observar do alto a vida dos homens de nivel inferior. Cf. PLATÃO - Sofista, 216c.

a Cf. Hegel, op. cit., p. 12.

Idem, p. 12 .

is Idem, p. 11. 
universais, então viva a arte! Viva a realização sensivel do universal! A arte era escada gloriosa, quem fosse capaz de galgar seus degraus era candidato à feliz elevação ao "divino"; do alto de seus degraus o ouvido ganhava a sensibilidade para escutar os belos sons da música e da poesia; subindo ao topo os olhos passavam a ver com nitidez as imagens que de baixo eram apenas figuras disformes e sem beleza. Mas as escadas só servem para quem não tem asas e precisa suar antes de se refrescar na brisa das alturas; para os que voam a escada é desnecessária. Na maturidade dos tempos o espírito liberta-se do pesado fardo da matéria. "De si mesmo o espírito extrai as obras artísticas que constituem o primeiro anel intermédio destinado a ligar o exterior, o sensível e o perecível ao pensamento puro, a conciliar a natura e a realidade finita com a liberdade infinita do pensamento compreensivo."”

"[...] Por agora, contentemo-nos em observar que a arte, até pelo seu conteúdo, se encerra em certos limites, que atua sobre a matéria sensivel e, portanto, apenas tem por conteúdo um determinado grau de verdade" ${ }^{\text {æ }}$ A medida com que a finitude remete à infinitude é a mesma com que a falsidade da parte conduz à verdade do todo. O limite da parte é ser parte, eis sua deficiência. A arte vivia no tempo em que o olho carecia do conteúdo da matéria trabalhada para vislumbrar o ideal, mas de tanto buscar "o além de ..." o "olho" aprendeu a ver sem carecer de intermediações, aprendeu a transpor o sensivel. A intelecção da visão é a morte da arte, isso significa que o espirito infinitamente livre é quem determina a verdade da arte. Ora, se o espírito careceu da arte, no passado, como espelho, hoje ele se espelha em si mesmo e, por isso, a arte morreu. A arte só foi arte enquanto o espirito permaneceu nela, sua morte corresponde à retirada do espírito. $\mathrm{O}$ apogeu da arte foi a infância do espirito, a maturidade do espírito, portanto, é a arte envelhecida, reminiscência, coisa do passado.

\begin{abstract}
"Os bons tempos da arte grega e a idade de ouro da última Idade Média são idos. As condiçōes gerais do tempo presente não são favoráveis à arte". "Em todos os aspectos referentes ao seu supremo destino, a arte é para nós coisa do passado. Com sê-lo, perdeu tudo quanto tinha de autenticamente verdadeiro e vivo, sua realidade e necessidade de outrora, e encontra-se agora relegada na nossa representação". ${ }^{p}$
\end{abstract}

Isso esclarece também que o considerado arte nas eras simbólica e clássica perdeu sua especificidade na romântica era hegeliana. Porque a obra de arte não define o que é arte, pode-se entender esse movimento do pensamento que tornou possivel a expressão: "a arte é coisa do passado". A arte é obra do espírito, cabendo apenas ao espírito determiná-la. Em Hegel não teria sentido a distinção que ingenuamente se faz hoje, quando se coloca de um lado as obras de arte do passado e de outro as chamadas artes modernas; filosoficamente essas obras não se distinguiriam, já que não se está fazendo uma crítica de arte ou uma história da arte, mas uma filosofia da arte: a distinção existente é empírica e não filosófica. Isso elucida o equívoco que contrapõe as expressões artísticas do passado com a arte moderna, afirmando umas e negando outras. O que se impõe para Hegel é

Idem, p. 12 e 13.

Idem, p. 13.

Idem, p. 13. 
que tanto "na arte como no pensamento, é a verdade que procuramos", ${ }^{\circ}$ e que "a arte é, pois, incapaz de satisfazer a nossa última exigência de Absoluto”. ${ }^{\circ}$

\section{3 - A passagem do Conceito à autonomia}

A radicalidade com que Hegel elaborou seu pensamento nos possibilita extrair duas conseqüências. A primeira, com Hegel, é a morte da arte e a segunda, sem Hegel, é o renascimento da arte enquanto instância irredutível ao conceito. Se encaminhamos nossas conclusões a partir dessas duas conseqüências não só entenderemos o projeto filosófico hegeliano como também compreenderemos aquilo que mais tarde se denominou arte moderna. Hegel é, portanto, o divisor entre a arte conceitual - carente de justificação - e a arte autônoma.

Não podemos dizer que houve autonomia absoluta da arte antes de Hegel, porque as configurações artísticas particulares do passado - arte simbólica, clássica e romântica - estavam sempre apontando para o meta-artístico, para uma instância de determinação plena que através da arte ganhava uma deficiente determinação e, paradoxalmente, quanto mais a instância para a qual a arte se remetia ganhava determinação, mais a arte perdia sua identidade. A arte do passado era sempre deficitária e dependente e só por isso era arte.

Podemos dizer, ainda, que se entendemos a arte como um subsistema (idéia do belo) do sistema hegeliano, então podemos falar em autonomia relativa da arte, quando da realização da forma particular de arte a que Hegel denominou romântica. Mas, exatamente a autonomia relativa da arte (romântica) a conduziu para a morte, pois o passo seguinte do progresso do espíito foi a assunção do subsistema pelo sistema (razão absoluta). Nisso consiste o resgate da multiplicidade para a unidade, o caminho do abstrato para o concreto, do indeterminado para o determinado. No entanto, esse resgate não pode ser entendido como retorno, porque agora a sintese final não corresponde à sintese inicial, é qualitativamente superior: é realização do espírito.

Para que possamos entender o que foi dito acima é necessário tomar as três definições das artes particulares do passado dadas por Hegel: ${ }^{*}$

"Temos, em primeiro lugar a arte simbólica. Nela, a idéia procura ainda a sua verdadeira expressão artística; ainda indeterminada e abstrata, não tem em si mesma os elementos de sua manifestação exterior e acha-se em face da natureza e dos eventos humanos, que the săo extrinsecos".

"Logo, em segundo lugar, nos aparece que a idéia em consonância com o seu conceito, não pode ficar na imprecisão e na abstração das idéias gerais. Por si mesma, é ela uma subjetividade livre e infinita que apreende, como espirito, na realidade. [...] Esta simples adequação do conteúdo e da forma constitui a segunda forma da arte, a arte clássica."

“Quando, em terceiro lugar, a idéia do belo se concebe a si mesma como sendo o espírito absoluto e, por conseguinte, livre em si e para sí, já ela não tem a possibilidade de se realizar plenamente por meios exteriores, pois só como espirito existe. Assim destrói ela a fusão

\footnotetext{
Idem, p. 12.

Idem, p. 13.

Hegel - Estética, p. 173.
} 
entre o fundo interno e a manifestação exterior, que havia sido realizada pela arte clássica, e regressa a si mesma. $\mathrm{E}$ assim surge a arte romântica $[. .]$.$" .$

Quando na arte romântica o espírito se concebe a si mesma como espírito absoluto, a arte morre e o espírito prossegue para a realização da idéia enquanto tal, essa realização final do espírito é o conceito que consumiu a arte. Por isso, enquanto se realiza na história através de manifestações artísticas particulares exteriores a arte é carente e dependente.

O progresso do espirito na história da arte acontece da idéia indeterminada do belo para a sua determinação, do símbolo (representação) à realidade (conceito). $\mathrm{Na}$ arte simbólica a idéia ainda indeterminada e abstrata, acha-se em face da natureza e está à procura da sua verdadeira expressão artística, da sua verdadeira determinação. O tempo da arte simbólica é o tempo da ameaça da natureza ao homem, portanto, ela é a expressão do não saber, a experiência do inatingivel. A natureza enquanto sublime, aparece como subjetividade.

A arte clássica produz o conhecimento teórico e prático; aqui a produtividade da arte tem relação simétrica com o saber. "A idéia em consonância com o seu conceito, não pode ficar na imprecisão e na abstração das idéias gerais". Não é mais a natureza que aparece como subjetividade, mas a idéia mesma é uma "subjetividade livre e infinita que apreende, como espirito, na realidade".

Na arte romântica acontece uma nova assimetria entre produção artística e saber teórico, não a assimetria em que o saber estava submetido à experiência estética, como na arte simbólica, mas exatamente o seu inverso. Na arte romântica o saber teórico submete a poiesis, determinando-a; a experiência estética é submetida pela autonomia da razão.

A assimetria entre a experiência artística e o saber teórico na arte simbólica representa a carência conceitual da arte. A simetria entre poiesis e saber teórico na arte clássica já apresenta a arte conformada ao conceito do belo, ainda não atingido pela arte simbólica. A arte clássica é a expressão artística por excelência para Hegel: " $E$ no ideal que se encontra realizada aquela união entre o conteúdo e a forma, que caracteriza a arte clássica. Esta satisfaz assim, devido a essa representação adequada, as exigências da arte verdadeira, da arte que é conforme ao seu conceito". "Nota-se que a referência artística por excelência para Hegel está na arte clássica porque ali a produção artística se adequa ao conceito. Nesse sentido não se pode dizer que há ali uma simetria legítima entre arte e conceito; o que há de fato é uma adequação da arte ao conceito, há, pois, uma primazia do conceito. A primazia do conceito latente na arte clássica se explicita na arte romântica; aí o conceito submete a experiência estética, engole a arte, sufoca-a e mata-a.

O limite da arte bela é também o seu fim. Quando na arte romântica o ideal alcança sua plena e completa realização, aquilo que é expresso exteriormente já não pode ser reconhecido como autêntico. A conciliação final com o absoluto implica a dispensa de qualquer expressão exterior e sensivel da arte. Neste ponto, o espirito se contempla a si mesmo sem carecer de mediações. Aqui a arte já não

31 Idem, p. 241. 
é arte no mundo ou, dito de outra forma, a arte morre para o mundo e se realiza plenamente no espírito, dessa maneira, continua arte, mas arte realizada no espirito, arte conciliada dialeticamente no todo.

"O conteúdo substancial das representações de arte romântica é a subjetividade absoluta, a união do espírito com sua essência, a pacificação da alma, a conciliação de Deus com o mundo e, portanto, consigo mesmo. Parece, pois, que é nesta forma de arte que o ideal há de encontrar a sua plena e completa realização. [...] A conciliação com o Absoluto apresenta-se, na arte romântica, como um ato que se efetua na mais intima profundidade e que, embora se exprima exteriormente, nessa expressão exterior não reconhece a sua verdadeira forma, o seu conteúdo e fim autênticos."

Já dissemos acima que para Hegel a verdade é o todo e as partes isoladas são "falsidades". No passado, portanto, a arte, nas suas manifestações particulares, não atingiu a Idéia em si. Como nenhuma manifestação particular da arte bela é capaz de determinar a Idéia em si, então, na história da arte, o todo da arte só é possível no conceito. No conceito a arte é negada e conservada. Negada enquanto despida de configurações particulares e conservada enquanto realização plena da idéia do Belo. A arte romântica é a fronteira entre a arte negada e a arte conservada, a arte do mundo e a arte do espírito. Arte romântica é ao mesmo tempo uma forma particular de expressão artística e a sintese final da arte bela.

$\mathrm{O}$ que acontece, enquanto síntese final no Conceito, é o resgate do todo que se realiza na história em formas particulares. O desenvolvimento do espírito na história tornou possivel a realização do sistema; no sistema o espírito se contempla a si mesmo na totalidade diferenciada. A idéia do Belo enquanto todo de diferenças essenciais que no passado se afirmou e realizou de formas particulares e indeterminadas é, no sistema, determinada e concretizada. Hegel destrói a tensão entre arte, religião e filosofia, matando, dessa forma, a arte, a religião e a histónia e realizando o totalitarismo de uma razão hegemônica. A contradição necessária para construir o sistema termina por ser suprimida no sistema. Sem diferença a identidade se impõe. $\mathrm{O}$ absoluto de Hegel em última instância é subjetividade radical, unidade sem diferença.

Hegel nos vem mostrar a absolutidade da Razão, o seu caráter necessário. A razão hegeliana é o purgatório da arte e da religião. Na morte da arte e na conseqüente morte da religião no sistema de Hegel, percebemos que a convivência harmônica e/ou tensa, no passado, entre filosofia, religião e arte se deveu à imaturidade dos tempos ou, se preferirmos dizer: somente na infância e na adolescência da razão existiu espaço para arte e religião. A filosofia madura supra-assumiu arte e religião; nesse sentido, é possivel concluir com Hegel que foi o déficit de razão o que tornou possivel a arte e a religião.

Até aqui apresentamos a primeira conseqüência da radicalidade do pensamento de Hegel que desembocou na morte da arte bela. Dissemos anteriormente que a conclusão derivada desta primeira conseqüência proveio do diálogo com Hegel. A segunda conseqüência possivel é a irredutibilidade da arte ao Conceito, portanto, sua existência autônoma, porém, esta conclusão só pode ser tirada se

3. Idem, 298-299. 
caminharmos para além de Hegel. É esse o tour feito para se chegar ao conceito de arte modema.

Antes, porém, de fazermos algumas considerações sobre a arte moderna, é importante voltarmos a Hegel para nos perguntar o que tornou possivel a morte da arte no seu sistema. E, sobre isto, talvez a explicação esteja no fato de que ele não deu conta da tarefa a que se propôs: conciliar o eu livre de Kant com a substância de Espinosa. A morte da arte em Hegel aconteceu exatamente pelo aprisionamento da liberdade no Conceito. Mas para que possamos pensar a arte enquanto instância irredutivel ao Conceito se faz necessária a manutenção da pergunta pela verdade da arte e a possibilidade ineliminável do novo. Em Hegel não há perguntas, somente respostas; da mesma forma não há o novo enquanto tal - a contingência - mas apenas e, em última instância, a necessidade. Pode-se dizer, a partir daí, que a identidade em Hegel é hegemônica e absoluta e a diferença é eliminada e, também, que a razão hegeliana atingiu a suprema subjetividade e determinidade. Cabe aqui a observação de Tugendhat: " $A$ filosofia hegeliana é consciente $e$ explicitamente a filosofia da justificação do existente."

\section{4- A arte moderna}

Por que a arte, independente e irredutível ao saber teórico, aparece exatamente depois de Hegel? Talvez a própria inexorabilidade do tempo tenha se encarregado de mostrar a impossibilidade de uma razão subjetiva absoluta. A história continuou, apesar de Hegel e a razão moderna hegemônica foi profundamente questionada, tripudiada e negada. Se hoje quisermos salvar a razão das investidas do irracionalismo temos que concebê-la como estruturalmente intersubjetiva. A reviravolta hermenêutica afirmou a historicidade e a contingência como instâncias inelimináveis do pensamento filosófico, embora para isto e em última instância, não tenha proposto uma fundamentação. Se, de um lado, não justificarmos a contingência ela impõe-se dogmaticamente e, se, de outro lado, submetemo-la a uma conceitualização, então recairemos no necessitarismo. É este um impasse sem saida ou uma pergunta que permanece em aberto?

Seguiremos agora considerando algumas elaborações de Gadamer que em contato com a tradição e, especialmente, com o pensamento heideggeriano pretende afirmar uma outra visão, em que a obra de arte é entendida como processo de construção e reconstrução contínuas e, nesse sentido, Gadamer assume a crítica de Heidegger contra a filosofia subjetivista moderna, abandonando o modelo da autoconsciência e assumindo a referência do modelo da autodeterminação. Aqui está talvez o distanciamento do projeto moderno gadameriano em relação ao projeto de Hegel. Porque na formulação hegeliana a verdade da autoconsciência é o espírito e só o espírito é a autoconsciência realizada, podemos dizer com Tugendhat que "pode ser que hoje já não seja possivel fundamentar a concepção de uma práxis racional no conceito de autoconsciência, nem sequer na versão refinada de Hegel". ${ }^{\text {* }}$

Cf. Ernst Tugendhat - Autoconciencia y autodeterminación, p. 274.

* Cf. Tugendehat, op. cit., p. 10. 
Do modelo da autoconsciência tratamos acima com Hegel. Neste modelo a verdade é razão absoluta, subjetividade radical. Por isso, tudo em Hegel desemboca na autoconsciência, sendo esta a instância suprema de autonomia; o fim último de todas as coisas, portanto, o fim último da arte. Ora, a posição defendida por Gadamer é a de que a arte moderna não é meio para..., mas tem fim em si mesma, é autônoma, e isso implica um rompimento definitivo com a posição hegeliana. Segundo Gadamer "desde que a arte não quis ser nada mais que arte começou a grande revolução artística moderna". Há, pois, um deslocamento do modelo da autoconsciência para modelo o da autodeterminação.

\begin{abstract}
"Já tratando de discemir a genealogia do belo, partindo do grego Kalós, Gadamer nomeia, como feito fundamental, sua autodeterminação". "Daí que para nossa sensibilidade mais natural, ao conceito do belo pertença o que não pode perguntar-se pelo que gosta. Sem nenhuma referência a um fim, sem esperar utilidade alguma, o belo se cumpre em uma espécie de autodeterminação e transpira o gozo de representar-se a si mesmo." ${ }^{36}$
\end{abstract}

A primeira observação que deve ser feita aqui é a de que romper com o modelo da autoconsciência é romper com a filosofia da subjetividade, portanto, romper com uma razão adestradora e, em última instância, necessitária. A segunda observação é a de que assumir o modelo da autodeterminação significa, antes de mais, abrir espaço para a pergunta pela verdade, isto quer dizer dar lugar ao possível, portanto, sair dos limites da necessidade e conviver com a continência. A pergunta pela verdade é, portanto, o critério da autodeterminação. As palavras de Tugendhat, quando se pergunta o que significa autodeterminação, dizem bem 0 sentido que estamos pretendendo dar aqui para este termo:

\begin{abstract}
"[...] temos visto que a autonomia consiste numa determinada maneira de eleger que não se esgota na relaçăo reflexiva consigo mesmo, mas que está essencialmente determinada por ela, ou seja, está determinada pela pergunta pela verdade no triplice sentido da pergunta pela realidade (o próprio ser e o ser social), o possivel e o melhor. 0 critério então é primordialmente a pergunta pela verdade. Quem assim atua, atua de maneira autônoma. Não se deixa determinar, mas sim atua segundo o critério que lhe dá sua própria tomada de posiçảo deliberativa."
\end{abstract}

Assumo aqui a interpretação de que a passagem do modelo da autoconsciência para a autodeterminação é o pressuposto da passagem de uma concepção conceitual de arte para uma concepção autônoma. Com essa posição passo agora a dialogar com Gadamer, a partir dos três conceitos com os quais ele articula a unidade da arte: jogo, símbolo e festa. Vale ressaltar que esses três conceitos são pescados na experiência antropológica, portanto, se ao final do diálogo com Gadamer ainda carecermos de uma justificação filosófica da arte é porque o paradigma da autodeterminação também o carece.

Gadamer quer recuperar a pergunta pela verdade da arte. Lembremos que em Hegel a verdade da arte é parcial e, por isso mesmo, não é verdade, daí sua conseqüente "diluição" na totalidade do sistema. A autonomia da arte acontece a partir da sua libertação de uma conceitualização que impedia uma compreensão adequada do ser estético. Todas as concepções em que a arte era concebida como

3 Cf. Gadamer - La actualidad de lo bello: introdución de Rafael Argullol, p. 16.

$\$$ Cf. Tugendhat, op. cit., p. 270. 
uma referência à realidade ou como uma modificação desta serviram de obstáculo na afirmação do ser estético como fim em si mesmo. Quando a arte se liberta desses obstáculos é ai que ela é autônoma. Segundo Gadamer:

\begin{abstract}
"Conceitos como imitação, aparência, desrealização, ilusão, encanto, sonho, estão pressupondo a referência a um ser autêntico do qual o ser estético seria diferente. Diferentemente, a volta fenomenológica à experiência estética ensina que esta não pensa de modo algum desde o marco desta referência e que, pelo contrário, vê a autêntica verdade no que ela experimenta. Tal é a razão pela qual por sua essência mesma a experiência estética não pode se sentir decepcionada por uma experiência mais autêntica da realidade." ${ }^{3 / 1}$
\end{abstract}

Ao recuperar, portanto, a pergunta pela verdade, Gadamer atualiza o belo como experiência sempre nova e jamais esgotável e, dessa maneira, inscreve o ser estético no infinito mundo das possibilidades hermenêuticas, tornando possivel afirmar a arte enquanto conhecimento. É exatamente na experiência da finitude que se faz possível ao sujeito a compreensão da experiência estética. Experimentar a finitude é a condição de possibilidade de novas experiências, é o remédio contra o subjetivismo totalizante, é a afirmação da historicidade e da contingência.

Partindo da tradição heideggeriana, Gadamer vai mostrar que "a compreensão não é um modo de comportamento do sujeito, mas uma maneira de ser do 'eis-aí-ser"'." E ao deslocar a compreensão do sujeito para a existência histórica Gadamer retira do sujeito o conhecimento e o transfere para a historicidade. É nesse contexto hermenêutico que se pode dizer que arte é conhecimento.

Quando Gadamer utiliza o conceito de jogo para defender a unidade da arte, ele quer referir-se à autonomia de movimento e ao desinteresse em atingir um fim para além de si mesmo que este conceito encerra. Pois é no conceito de jogo que ele pretende demonstrar uma visão dinâmica da experiência estética, na qual a obra de arte é entendida como um contínuo processo de construção e reconstrução, deixando pra trás uma visão fechada e cristalizada de arte.

"Nossa tese é, pois, que o ser da arte näo pode determinar-se como objeto de uma cons-
ciência estética, porque ao invés o comportamento estético é mais que o que ele sabe de sí
mesmo. É parte do processo ôntico da representaçâa, e pertence essencialmente ao jogo
como tal"."

O jogo é o lugar do possível, se a contingência for eliminada o jogo já não é jogo. Jogar é preencher continuamente o espaço sempre existente; é uma atividade que requer participação, por isso, o sentido do jogo só é alcançado na necessária mediação do ato de jogar. 0 jogo só é plenamente jogo quando está sendo jogado.

A ressalva inicial feita por Gadamer é a de que o conceito de jogo deve ser liberado da significação subjetiva dada por Kant e Schiller; a ele interessa vincular esse conceito à própria obra de arte. É, pois, significativo o deslocamento do conceito da esfera do sujeito para a esfera da obra: é a obra de arte que deve ser pensada como um jogo, como um contínuo processo de construção e reconstru-

I Cf. Gadamer - Verdad y método, p. 123-124.

Cf. Manfredo Oliveira - Reviravolta linguístico-pragmática na filosofia contemporânea, p. 225.

Cf. Gadamer - Verdad y método, p. 161. 
ção, em que a significatividade brota à medida que o espaço sempre aberto e em movimento da obra vai sendo preenchido.

Cabe aqui a distinção gadameriana entre o jogo mesmo e o comportamento do jogador. Se a obra de arte deve ser pensada como um jogo, então vale perguntar pela essência mesma do jogo. Já podemos adiantar que essa resposta não será jamais encontrada na reflexão subjetiva do jogador, mas, somente, no próprio jogo. Como é claro para Gadamer que o jogo só é jogo enquanto está sendo jogado e, portanto, "o jogo só cumpre o objetivo que lhe é próprio quando o jogador se abandona de todo ao jogo", "então, é dessa compreensão que ele infere o caráter efêmero da obra de arte. A efemeridade não é a impossibilidade de representação da obra, mas, antes, é a sua condição de possibilidade, pois é essa a sua forma de auto-representação. A obra de arte é o lugar da criação contínua, ela é presença plena num movimento simultâneo de desvelamento e ocultação e, nesse sentido, o distanciamento da obra de arte, realizado por um sujeito exterior a ela, degenera-a e a torna uma produção des-figurada e sem representação própria.

A essência do jogo revela essa tensão permanente entre finitude e infinitude. No ato de jogar estão postas as infinitas possibilidades intrinsecas ao jogo, mas o que se efetiva nas "jogadas" tem como marca a finitude. Da mesma maneira, na obra de arte estão as infinitas possibilidades de atuação significante e de desvelamento do "belo", mas o efetivamente atualizado é como um rasgo de luz na imensidão do céu. A obra de arte, assim como o jogo, é o lugar da tensão permanente entre imanência e transcendência, e esta é para Gadamer a garantia da irredutibilidade da arte ao conceito (do jogo à representação do jogador), aqui reside a autonomia da obra de arte. É nesse contexto que se coloca a afirmação de Gadamer: "o sujeito do jogo não são os jogadores, mas sim que através deles o jogo simplesmente realiza a sua manifestação"."

Quando Gadamer utiliza o conceito de jogo para construir a resposta à pergunta pela essência da obra de arte, ele tem a intenção de expressar movimento: "o jogo é a pura realização do movimento"." Isso parece paradoxal. Mas, assim, ele quer responder à pergunta pela verdade da obra de arte sem, contudo, dizer positivamente o que é arte.

Gadamer fez algumas observações de ordem lingüistica bastante esclarecedoras sobre o conceito de jogo. Com isso ele pretendeu mostrar que o verdadeiro sujeito do jogo é o jogo mesmo. Há uma inversão do vetor epistemológico: não é o jogador quem faz o jogo, mas sim o jogo que faz o jogador, por isso, "todo jogar é um ser jogado".

"Joga-se um jogo. Em outras palavras: para se expressar o gênero de atividade de que se trata tem que se repetir no verbo o conceito que contém o substantivo. Dá toda a impressão de que isto significa que se trata de uma ação de caráter tão especial e particular que cai fora das formas habituais de ocupação. Jogar não é um fazer no sentido usual da palavra"."

* Cf. Gadamer, Verdad y metodo, p. 144.

Idem, p. 145.

2. Idem, p. 146.

- Idem, p. 149.

" Idem, p. 146. 
A autonomia do jogo está configurada na sua auto-representação. O jogo é uma tarefa que se cumpre à medida que é realizada. O jogo é sempre tarefa, é contínua construção. $O$ jogo ideal não existe porque "o jogo se limita realmente a representar-se. Seu modo de ser é pois a auto-representação"." Do mesmo modo a obra de arte. Para Gadamer uma obra nunca está pronta, pois ela sempre pode ser novamente atualizada. O que isso significa? Significa que assim como o jogo é feito jogo à medida que se realiza para alguém, do mesmo modo, a obra de arte é uma "transformação em uma construção"."

“[...] transformação quer dizer que algo se converte ínstantaneamente em outra coisa completamente distinta, e que esta segunda coisa na qual se tem convertido por sua transformação é seu verdadeiro ser, frente ao qual seu ser anterior não era nada. [...] Nosso giro 'transformação em uma construção' quer dizer que o que havia antes já não está agora"."

Podemos então dizer, com Gadamer, que a verdade da obra de arte se encontra "sempre num horizonte futuro de possibilidades desejadas e temidas, em todo caso de possibilidades todavia não dirimidas". A obra de arte como o jogo, é um horizonte de possibilidades. Somente enquanto horizonte a obra de arte é construção possivel, sempre passivel de transformação; um espaço de perene realização do novo.

A busca de resposta à pergunta pela verdade da arte continua a ser perseguida por Gadamer no conceito de símbolo. Da mesma maneira que a essência do jogo é o automovimento a essência do simbólico é a auto-significação. Também no conceito de símbolo está presente a tensão ineliminável entre finitude e transcendência, isto é expresso no jogo de revelação e ocultamento do belo na arte.

A imagem que Gadamer nos proporciona remonta à tradição grega antiga. Entre os gregos a palavra símbolo teria sido originada como uma tabuleta de recordação. Conta-se que ao se hospedar numa casa, o hóspede recebia do seu anfitrião a metade de uma tabuleta cindida em duas partes naquela ocasião; a outra metade o próprio dono da casa a guardava. Essa era a senha do reconhecimento, para que mais tarde, passados muitos anos, quando o hóspede voltasse à casa pudesse reconhecer seu anfitrião e ser por ele reconhecido, no ato de ajuntamento das duas partes da tabuleta. Essa tabuleta era, segundo Gadamer, uma espécie de "passaporte" na época antiga e esse é o sentido técnico originário da palavia símbolo.

Lembremos que no Banquete, "num belíssimo discurso sobre o amor, Platão relata uma história parecida. No discurso de Aristófanes sobre a natureza do amor, conta-se que outrora á constituição humana não era a mesma de hoje, em vez de "incompleta" e "imperfeita" era completa e perfeita como uma esfera. Consta que a espécie humana se dividia em três gêneros: o masculino, o feminino e o andrógino. Cada uma das três figuras era inteira, portanto, sem necessidades ou carências e, por isso mesmo, inflados de um orgulho imenso, a tal ponto que quiseram medir forças com os deuses e se comparar a eles. Diante disso, Zeus e os outros

\footnotetext{
*. Idem, 151.

s Idem, 154.

- Idem, 155

* Cf. Platão, Banquete.
} 
deuses deliberam e resolveram pôr fim à insolência da humanidade, separando os gêneros em duas partes. Assim, o masculino foi dividido ao meio, da mesma forma o feminino e o andrógino e, além disso, foram lançados em lugares diversos, de modo que cada parte recebeu o castigo da incompletude e da insatisfação, vivendo à busca de sua metade. $\mathrm{O}$ amor seria, portanto, o re-encontro das metades, fazendo recobrar a antiga sensação de força e harmonia, a tal ponto que após o reencontro as partes não querem mais se separar, nem sequer por um instante.

Essa história, também retomada por Gadamer, aponta para a experiência da arte, como um momento intenso de re-encontro. A partir dessas alegorias já podemos nos remeter à importância dada por ele ao significado da palavra símbolo para o entendimento da arte. A primeira idéia aí colocada é a da unidade, lembrada na integridade original da tabuleta ou dos gêneros. O símbolo se configura como uma parte de um todo que só se realiza no encontro com sua metade complementar, o que implica reconhecimento da unidade. É nesse sentido que a experiência da arte é para Gadamer, a fala da obra de arte trazida à tona através da reunião de partes, antes separadas, tornando possível assim a unidade da oração.

A segunda idéia é a do retorno às origens que torna possivel a unidade de uma identidade cindida e a significatividade do encontro entre velhos amigos (anfitrião e hóspede). O símbolo não representa algo diferente de si, mas se autorepresenta; o símbolo é a parte imprescindível ao todo, é mediação necessária de sentido. Por isso, o simbolo não pode ser descartado ou substituído, pois ele é o passaporte para a experiência artística, é a ponte para a festa do re-encontro. Com isso, Gadamer mostra a irredutibilidade da arte ao conceito e, portanto, a atualidade ineliminável do artístico.

\begin{abstract}
"[...] o símbolo, a experiência do símbolo, quer dizer que este individual, este particular se representa como um fragmento de Ser que promete complementar num todo íntegro que se corresponda com ele; ou, também, quer dizer que existe o outro fragmento, sempre buscado que complementará num todo nosso próprio fragmento vital".
\end{abstract}

Poderiamos pensar no belo como um todo íntegro que se desvela em duas partes, uma das quais é o símbolo e a outra o significado, de modo que uma parte sem outra não tem sentido. Nesse jogo, o símbolo só é reconhecido pela sua parte complementar - o significado - e este, por sua vez, só é alcançado através do simbolo. Dessa maneira, o infinito se atualiza (torna-se ato) na finitude, o universal no particular. Se tomamos a obra de arte como uma das partes do todo íntegro - a arte - ela é o particular no qual repousa a possibilidade de reconhecimento do universal - 0 belo. Aqui reconhecer significa retornar à origem onde as duas partes ainda não estavam cindidas, "re-conhecer na arte é captar a permanência no fugitivo". .

Essa é, sem dúvida, a resposta mais clara de Gadamer à pergunta pela verdade do belo e da arte. A experiência vivida na arte é a da finitude des-ocultando a infinitude, portanto, não é uma experiência de finitude, mas de transcendência; do mesmo modo, podemos entender o encontro com a arte como uma experiência de

4. Cf. Gadamer, La actualidad de lo bello, p. 85.

so Cf. Gadamer, La actualidad de lo bello. Introdução de Rafael Argullol, p. 22. 
totalidade, porque "no particular de um encontro com a arte não é o particular o que se experimenta, mas sim a totalidade do mundo 'experimentável' e da posição ontológica do homem no mundo [..." ". No entanto, para Gadamer nenhuma experiência estética é capaz de esgotar o sentido da obra de arte. Ninguém, pois, será jamais capaz de se apropriar da totalidade do belo, esgotando-o. Isso quer dizer que a experiência artística é indeterminada e que a posição ontológica do homem no mundo é claramente a finitude, uma tarefa contínua. Daí porque a essência do simbólico na arte consista essencialmente na sua não referência a um fim destacado de si mesmo, por meio de um significado alcançável intelectualmente; mas, ao contrário, o simbólico aqui tem fim em si mesmo, isto é, detém em si signo e significado.

A triade conceitual utilizada por Gadamer para caracterizar a essência da arte se completa com o conceito de festa. Por quê? Devemos entender festa aqui como celebração; celebrar é sair do isolamento e participar do encontro; celebrar é sair do tempo cronológico e chegar ao tempo sagrado. A festa é uma atividade comunitária, quer dizer, é a comum unidade de intenções que impede a dispersão dos indivíduos. Toda celebração é auto-representativa, não é mediação para outro fim, mas é o próprio ponto de chegada. Gadamer compara a festa com um organismo vivo, entendido enquanto "algo que está centrado em si mesmo, de sorte que todos os seus elementos não estão ordenados segundo um fim terceiro, mas servem à própria autoconservação e vida do organismo"'s. A festa não é um ponto previamente estabelecido no calendário, mas é a celebração significativa de um encontro; se não há encontro não há o que ser celebrado, portanto, não há festa.

Inserido na tradição heideggeriana, Gadamer entende a festa enquanto celebração do encontro entre Ser e Tempo, por isso, o tempo da festa não é uma série de momentos sucessivos, mas é tempo transcendente, sagrado. Na festa não se dispõe de tempo, mas, ao contrário, o tempo está à disposição da festa. A festa não está no tempo, mas tem seu próprio tempo. É nesse sentido que Gadamer entende a experiência na arte, como um tempo pleno, tempo próprio. $\mathrm{Na}$ arte somos convidados a demorar-nos, ou seja, a sair do tempo calculável e dividido e experimentar a eternidade. $\mathrm{O}$ aprender a demorar-se é, para Gadamer, a própria essência da experiência temporal da arte porque a demora é o correspondente na finitude ao que chamamos eternidade.

Os três conceitos apresentados por Gadamer expressam na arte a experiência da finitude da existência humana. A finitude representada pelo Tempo é o lugar do desvelamento da infinitude do Ser. $\mathrm{Na}$ experiência artística se vivencia a simultaneidade de passado e presente: no jogo somos jogados na "arbitrariedade" do ser e vivemos a liberdade de ser, simplesmente sendo; no símbolo "reconhecemos" a significatividade ontológica originária da existência humana captamos o permanente no efêmero, afirmamos nossa finitude; na festa atualizamos a tradição, sintonizamos na mesma freqüência e cantamos na mesma língua. A festa é a celebração do eterno, jamais roubado pelo tempo.

51 Idem, p. 86. Grifo meu.

(2) Idem, p. 106. 


\section{5 - Nota final}

Percebemos que se situamos nossa concepção de arte na perspectiva do conceito, então caimos no modelo da autoconsciência que, se levado às últimas conseqüências, engole a arte e mata-a, como aconteceu em Hegel. Por outro lado, se defendemos que na obra de arte se experimenta uma verdade que não pode ser encontrada por caminhos estranhos à arte, então assumimos o modelo da autodeterminação, aquele em que a pergunta pela verdade é sempre atual e jamais dispensável. Podemos dizer que, no primeiro modelo, olhamos a arte de fora $\mathrm{C}_{4}$ como um sujeito diante de um objeto e, no segundo modelo, só é possível "enxergá-la" na própria experiência da arte, portanto, colocando-nos do lado de dentro, participando do jogo, rompendo com o modelo sujeito-objeto.

Entre a Arte Bela e a Arte Moderna há um rio; de um lado de sua margem há a necessidade, do outro lado a contingência; do lado da necessidade a arte é prisioneira do conceito, do lado da contingência ela é contínua construção, é livre, é criação. A travessia deste rio é feita, a pé enxuto, através de uma ponte. Quão espetacular obra de arte é esta ponte que une necessidade e contingência! $O$ que podemos dizer sobre ela? Eis um problema "quase" insolúvel. Se definimos a ponte, colocamo-nos do lado da necessidade e matamos a contingência. Se nos colocamos do lado da contingência, então, não a podemos definir, e aí, como sabemos que há ponte? Sem referência estamos perdidos. E agora, o que fazer? O que é Arte? Bom, pelo menos estamos nos perguntando, e quando uma pergunta é feita é porque, no mínimo, aponta para uma resposta. A possibilidade de respostas é o ideal necessário para mover todas as perguntas. E porque perguntamos somos livres, abrimos a possibilidade da contingência. Perguntar é o efetivo ato de liberdade, é pressupor, sem deixar de acreditar no possivel.

\section{Referências Bibliográficas}

DE BONI, Luis A. (Org.). Finitude e transcendência. Petrópolis: Vozes, 1996.

DUARTE, Rodrigo A. P. (Org.). Anais: morte da arte. Belo Horizonte: Laboratório de Estética da FAFICH/UFMG, 1993.

GADAMER, Hans Georg. La actualidad de lo bello. Barcelona: Paidós / I.C.E. - U.A.B., 1991.

- Verdad y metodo I, 5. ed. Salamanca Ediciones Sigueme, 1993.

HEGEL, G. W. F. Estética. Lisboa: Guimarães Editores, 1993.

. Fenomenologia do espírito, 2. ed. Petrópolis (RJ): Vozes, 1993.

OLIVEIRA, Manfredo A. de. Reviravolta Lingüístico-pragmática na filosofia contemporânea. São Paulo: Loyola, 1996.

PLATĀO. O Banquete. Tradução de José Cavalcante de Souza \& Outros. São Paulo: Abril Cultural, Coleção Os Pensadores, 1983.

- Fedro. Tradução de Carlos Alberto Nunes. Belém: Universidade Federal do Pará, 1975.

Os Pensadores, 1983.

TUGENDHAT, Emst. Autoconciencia y autodeterminación: una interpretación lingüistico-analítica. Madrid: Fondo de Cultura Ecónomica, 1993.

TUGENDHAT, E. \& WOLF, Ursula. Propedêutica lógico-semântica. Petrópolis (RJ): Vozes, 1997. 